\title{
Maternal health expenditures and health seeking behavior among lowest wealth quintile of the rural population in an under developed district of the Punjab, Pakistan
}

\author{
Mariam Sughra $^{1}$, Farwa Fatima ${ }^{1}$, Mouzma Marrium², Khizer Abbas ${ }^{3 *}$
}

\author{
${ }^{1}$ Department of Medicine, Nishtar Hospital, Multan, Pakistan \\ ${ }^{2}$ Department of Gynaecology, Avicenna Hospital, Lahore, Pakistan \\ ${ }^{3}$ Department of General Medicine and Surgery, Shaykh Zayed Hospital, Rahim Yar Khan, Pakistan
}

Received: 26 May 2018

Accepted: 11 June 2018

\section{*Correspondence: \\ Dr. Khizer Abbas, \\ E-mail: drkhizer01@gmail.com}

Copyright: ( ) the author(s), publisher and licensee Medip Academy. This is an open-access article distributed under the terms of the Creative Commons Attribution Non-Commercial License, which permits unrestricted non-commercial use, distribution, and reproduction in any medium, provided the original work is properly cited.

\begin{abstract}
Background: Expenditures on maternal health is important factor to determine the health seeking behavior in pregnant women among the lowest economical section of Pakistan. This study was carried out determine the maternal health expenditures and health seeking behavior among lowest wealth quintile of rural Rahim Yar Khan.

Methods: Sample Size: For this cross- sectional study, a total of 230 subjects were involved in the study from rural areas of Rahim Yar Khan including Basti Bahishti, Bah-o-Bahar and Chak 83/P. This study was comprised of duration of 06 months from 02/03/2016 to 04/09/2016. The head of Family (Husband) with monthly income less than 15000 Pakistani rupees (PKR) were included and marriage with in last 5 years with at alive delivery. While subjects having income more than $15000 \mathrm{PKR}$ and not willing to participate in study were excluded from the study.

Results: People with mean monthly income of PKR. 1176 \pm 4109 spent mean amount of PKR. $146442 \pm 7747$ on their marriages. While the mean expenses on treatment of complication in the last pregnancy were PKR. $35808 \pm 6771$ and the amount saved for the treatment of complication was PKR. 2750 \pm 1157 only. Mean antenatal expenses were PKR. $1807 \pm 3335$, Mean expenses on delivery were PKR. $7351 \pm 855$ as compared to the money saved for delivery was PKR. $6115 \pm 1460$. Mean expenses on complications during delivery were PKR. 1692 \pm 523 . Mean expenses on postnatal care were PKR.8596 \pm 3597 while the mean amount used for treatment of postnatal complications were of PKR. $2451 \pm 560$. Mean expenses on birth celebrations were of PKR. $7697 \pm 832$.

Conclusions: Present study reveals that there is a high financial cost of maternal health expenditures paid by the lowest wealth quintile in rural areas of Rahim Yar Khan when compared with the income of this quintile. Access of the people to the health sector is still limited due to low income of people, low health education and unavailability of health services in rural areas and even in 2017.
\end{abstract}

Keywords: Expenditures, Lowest wealth quintile, Maternal health, Rural population

\section{INTRODUCTION}

Pakistan is the sixth most populous country of 180 million people with population density 548.51. ${ }^{1}$ According to World Bank report, women are $48.6 \%$ of the population with an estimated life expectancy of 65.45 years. $^{2}$ Around 800 women across the globe die every day also considered as second leading cause of death after HIV infection among women of reproductive age. The causes of maternal deaths include severe bleeding, infections, unsafe abortions and hypertensive disorders. Pakistan total health expenditures amounted to $3.9 \%$ of gross domestic product (GDP) in 2005. And per capita health expenditures were $\$ 49$. The government provided 
$24.4 \%$ of total health expenditure, with the remainder being entirely private, out-of-pocket expenses. ${ }^{3}$ On the other hand, the situation is much more alarming in Pakistan where annual number of maternal deaths exceeds that of most of the countries in the world. The annual number of maternal deaths in Pakistan in 2013 was 7900 which is $2.6 \%$ of annual number of maternal death in the word. ${ }^{4}$ The Maternal mortality Rate in Pakistan is 276 maternal deaths per 100000 live births which is much high than the maternal mortality rate in the world. One of the leading causes among them is the poor economic circumstances leading to malnutrition, unhygienic condition, low health seeing behavior and lower expenditure on maternal health. ${ }^{5-7}$

Poverty in Pakistan has fallen dramatically, independent bodies supported estimates of a considerable fall in the statistic by the 2007-08 fiscal year, when it was estimated that $17.2 \%$ of the total population lived below the poverty line. ${ }^{8}$ The declining trend in poverty as seen in the country during the 1970 s and 1980 s was reversed in the 1990s by poor federal policies and rampant corruption. ${ }^{9}$ This phenomenon has been referred to as the "Poverty bomb"

The objectives of this study were to determine the maternal health expenditure among lowest health quintile of rural population of and also to determine the maternal health seeking behavior in rural areas of Rahim Yar Khan.

\section{METHODS}

For this cross-sectional study, a total of 230 subjects were involved in the study from rural areas of Rahim Yar Khan including Basti Bahishti, Bah-o-Bahar and Chak 83/P. This study was comprised of duration of 06 months from $02 / 03 / 2016$ to $04 / 09 / 2016$. The ethical approval was granted by the Institutional Review Board of Shiekh Zayed Hospital Rahim Yar Khan.

\section{Inclusion criteria}

- The head of Family (Husband) with monthly income less than 15000 Pakistani rupees (PKR)

- Marriage within last 5 years with an alive delivery

\section{Exclusion criteria}

- Subjects having income more than 15000 PKR

- Subjects not willing to participate in study.

\section{Statistical analysis}

The data was entered and analyzed by using SPSS version-20. Numerical variables like age, expenditure was presented as mean $\pm \mathrm{SD}$ and categorical variables like place of delivery, education was presented as percentages.

\section{RESULTS}

Mean expenses on the treatment of complications were $3581 \pm 6771$ PKR. Those who saved money for treatment of complications were $6(12 \%)$.

Mean money saved for the treatment of complication was $2750 \pm 11572$ PKR. Mean number of live births were $3 \pm 2$, number of antenatal visits in last pregnancy were $3 \pm 2$ and antenatal expenses $1808 \pm 3335$ PKR (Table 1).

Table 1: Descriptive statistics of monthly income, years of marriage and number of pregnancies.

\begin{tabular}{|lllll|}
\hline Characteristics & $\begin{array}{l}\text { Monthly income } \\
\text { (PKR) }\end{array}$ & Years since marriage & $\begin{array}{l}\text { Expenses on marriage } \\
(\text { PKR) }\end{array}$ & $\begin{array}{l}\text { Number of } \\
\text { pregnancy }\end{array}$ \\
\hline Mean & 11761 & 7.5 & 146442 & 03 \\
\hline Median & 10000 & 5 & 150000 & 02 \\
\hline Mode & 10000 & 4 & 200000 & 01 \\
\hline Std. deviation & 4109 & 6 & 77474 & 02 \\
\hline Range & 18000 & 19 & 300000 & 11 \\
\hline Minimum & 4000 & 1 & 00 & 01 \\
\hline Maximum & 22000 & 20 & 300000 & 12 \\
\hline
\end{tabular}

Frequency of delivery done at home was $21(40 \%)$, in private clinics were $11(21 \%)$ and in Govt. hospital were $20(39 \%)$. The frequency of delivery done by Dai was 17 $(33 \%)$, Trained mid wife was $4(8 \%)$, LHV was $5(10 \%)$ and DR was $26(50 \%)$. The frequency of delivery by $\mathrm{C}$ section was $18(34 \%)$, normal was $33(64 \%)$ and assisted was $1(2 \%)$ (Table 2). The mean expenses on delivery were $7352 \pm 8556 \mathrm{PKR}$. The mean expenses on cesarean section were PKR. 13639, normal delivery were PKR. 4206 and on assisted delivery were PKR. 1100. Those who saved money for delivery were $15(28 \%)$. The Mean money saved for the delivery was $6115 \pm 14607$ PKR. The frequency of complication in last delivery was $12(23 \%)$. The maternal complication in last delivery was $12(23 \%)$. The mean expenses on treatment of delivery complication were $1692 \pm 5236$ PKR. The frequency of post-natal care 
was $23(44 \%)$. The mean expenses on postnatal care were $860 \pm 3597$ PKR. Those who had postnatal complication were $14(26 \%)$. The Postnatal complications were maternal $1(2 \%)$, neonatal $11(21 \%)$, both $2(4 \%)$. The Mean expenses on the postnatal complications were $2452 \pm 5607$ PKR. The frequency of birth celebration was $38(73 \%)$. The mean expenses on birth celebration were $5625 \pm 7881$ PKR. The last child sex was boy $29(56 \%)$, girl $23(44 \%)$. The mean expenses on birth celebration were $7697 \pm 8320$ PKR (Table 3).

Table 2: Education status of the participants.

\begin{tabular}{|lll|}
\hline Education status & Frequency & Percent \\
\hline Illiterate & 14 & 26.9 \\
\hline Primary & 17 & 32.7 \\
\hline Matric & 13 & 25.0 \\
\hline F.Sc and above & 8 & 15.4 \\
\hline Total & 52 & 100.0 \\
\hline
\end{tabular}

Table 3: The frequency of complications in last pregnancy.

\begin{tabular}{|lll|}
\hline $\begin{array}{l}\text { Complications in } \\
\text { last pregnancy }\end{array}$ & Frequency & Percent \\
\hline No & 34 & 65.4 \\
\hline Yes & 18 & 34.6 \\
\hline Total & 52 & 100.0 \\
\hline
\end{tabular}

\section{DISCUSSION}

In Pakistan, health services are poor in general, but they are particularly deficient in maternal health leading to adverse outcomes for both women and newborns. Antenatal care is named as the one of the four pillars of safe motherhood initiative: although it's relative contribution to maternal health care has been under debate and its importance can't be denied. Moreover, people spend more money on childbirth celebrations than they save for pregnancy in case of any complication. According to present finding the literacy rate for the head of the family is $73 \%$ (Most of them were upto the matric). These rates are quite low when compared internationally. Education is significantly associated with utilization of maternal health services. These are a number of explanations for why education is a key determinant. Education is like to enhance female autonomy: women thereby develop greater confidence and capabilities to make decision regarding their own health as well as their children's health. It is likely that more educated women seek higher quality services and have greater ability to use health care inputs to produce better health. But in present society education does not shows any association because most of the people even mentioned in literate category had no years of schooling and could just read and write simple words. ${ }^{10,11}$

Husband's income and education serve as indicators to assess socio-economics status in this study $27 \%$ husbands were illiterate, and all were belong to a poor income group. The result of present research when compared with the research on "Maternal Health Care in Rural Areas of Pakistan". ${ }^{12}$ The incidence of obstetric complication was $34 \%$ in present research as compared to $38 \%$ in this research. Number of antenatal visits were same in both studies with mean of $3 \pm 2$ visits. $40 \%$ deliveries were done in home, $39 \%$ in govt. hospitals and $21 \%$ in private hospitals. ${ }^{13}$ There is contrast to above mentioned research where $75 \%$ deliveries were done in home, $20 \%$ in govt. hospitals and remaining in the private sector. In "Pakistan Demographic and Health Survey 2006-07, National Institute of Population studies Islamabad, Pakistan". ${ }^{14}$ People of lowest wealth quintile who saved money for any complication were $32.5 \%$. But in present survey only $12 \%$ people saved money for future complications with mean of PKR 2750 \pm 1157 meanwhile the complications occur in last pregnancy was in $34 \%$ cases and expenses they bear for treatment of complication was the mean of PKR $35808 \pm 6771$. This finding shows that people of lowest wealth quintile are not interested in saving for future complications even if they already know about the complications but still they invest a huge amount in treatment of complications if it happens. Frequency of postnatal complication was $26 \%$ as compared to above mentioned study in which it was $20 \%$ only. Present study revealed that $73 \%$ families in lowest wealth quintile celebrate their childbirth, with the mean amount of PKR 7697 \pm 832 .

\section{CONCLUSION}

Present study reveals that there is a high financial coast of maternal health expenditures paid by the lowest wealth quintile in rural areas of Rahim Yar Khan when compared with the income of this quintile. Access of the people to the health sector is still limited due to low income of people, low health education and unavailability of health services in rural areas and even in 2017. Present public health sector is not completely successful to provide free health services and health for all services at gross root level. It is suggested to provided health education to community and provides health services at lower coast in rural areas to improve the maternal health of the lowest wealth quintile people.

Funding: No funding sources

Conflict of interest: None declared

Ethical approval: The study was approved by the Institutional Ethics Committee

\section{REFERENCES}

1. Countries of the world: an interactive lat of countries including their estimated populations, as well as land densities. Available at www.worldatlas.com/atla/populations/ctypopls.htm.

2. Data the United Nation Population Division's World Population Prospects Available at www.dataworldbank.org/country/pakistan.html. 
3. WHO, UNICEF, UNFPA and The World Bank estimates, Trends in Maternal mortality: 1990 to 2015. Available

at

http://apps.who.int/iris/bitstream/handle/10665/1942

54/9789241565141_eng.pdf;jsessionid=42492E036A D342EBC0E96EAE725ADEB9? sequence $=1$ ) access ed on 27-5-2018.

4. Maternal health Available at http://mhtlf.org./topics/post-2015-whats-next _ formaternal-health/.

5. Badshah S, Mason L, McKelvie K, Payne R, Lisboa PJ. Risk factors for low birthweight in the publichospitals at Peshawar, NWFP-Pakistan. BMC Public Health. 2008 Dec;8(1):197.

6. Jokhio AH, Winter HR, Cheng KK: An intervention involving traditional birth attendants and perinatal and maternal mortality in Pakistan. $\mathrm{N}$ Eng $\mathrm{J}$ Med. 2005;352(20): 2091-9.

7. Malik MF, Kayani MA. Issues of maternal health in Pakistan: trends towards millennium development goal 5. J Pakistan Med Ass. 2014;64(6):690-3.

8. UNDP Reports Pakistan Poverty Declined to $17 \%$ UnderMushrraf" Pakistan Daily. 7 September 2009. Retriveved 2012-03-12.

9. Poverty in Pakistan: issues, Causes, and institutional Responses", Asia Development Bank. Available at https://scholar.google.com.pk/scholar?hl=en\&as_sdt $=0 \% 2 \mathrm{C} 5 \& \mathrm{q}=$ Poverty $+\mathrm{in}+$ Pakistan $\% 3 \mathrm{~A}+\mathrm{issues} \% 2 \mathrm{C}+$
Causes $\% 2 \mathrm{C}+$ and+institutional+Responses $\% \mathrm{E} 2 \% 80$ $\% 9 \mathrm{D} \% 2 \mathrm{C}+\mathrm{Asia}+$ Development+Bank\&btnG=

10. Pakistan: Now the poverty Bomb goes off, M, Ziauddin, Third World Network. Available at https://scholar.google.com.pk/scholar?hl=en\&as_sdt $=0 \% 2 \mathrm{C} 5 \& \mathrm{q}=$ Pakistan $\% 3 \mathrm{~A}+$ Now + the + poverty + Bom b+goes+off\&btnG $=$

11. Demographic and National Health Survey 20062007. National Institution of Population Studies Government of Pakistan.

12. Safdar S, Ahmed ST. Maternal Health care in Rural Areas of Pakistan. J Pakistan Med Ass. 2002;52(7): 308-11.

13. Pakistan Demographic and National Health Survey 2012-2013. National Institution of Population Studies, Islamabad, Pakistan. Available at http://dhsprogram.com/pubs/pdfFR290/FR290.pdf.

14. Pakistan Demographic and National Health Survey 2006-07, National Institution of Population Studies, Islamabad, Pakistan. Available at http://dhsprogram.compubs/pdf/FR200/FR200.pdf.

Cite this article as: Sughra M, Fatima F, Marrium M, Abbas K. Maternal health expenditures and health seeking behavior among lowest wealth quintile of the rural population in an under developed district of the Punjab, Pakistan. Int J Reprod Contracept Obstet Gynecol 2018;7:2579-82. 